National Marine

Fisheries Service

Fishery Bulletin

as established in 1881 ๙

\title{
Diet of harbor porpoises (Phocoena phocoena) on the continental shelf off southern New England
}

Abstract-Little is known about the
diet of harbor porpoises (Phocoena phocoena) in southern New England where bycatch was a highly contentious issue since the late 1990 s until recently. To fill this data gap, stomach contents were examined from 46 harbor porpoises taken as bycatch over 24 years (1994-2017) between January and May. Prey species were identified to the lowest possible taxon through hard part analysis, primarily of otoliths and squid beaks. Size and species of harbor porpoise prey overlapped little with those of gillnet catch. Average prey size was larger for adult harbor porpoises ( $\geq 140 \mathrm{~cm}$ total length), females, and those taken during the first half of our study (1994-2006) than for smaller porpoises, males, and those caught during the second half (2007-2017). Average total biomass consumed per stomach was $2.3 \mathrm{~kg}$, an estimate that represents approximately $12-24 \mathrm{~h}$ of feeding. Clupeids, true hakes (Urophycis spp.), squids (Decapodiformes), and silver hake (Merluccius bilinearis) constituted $85.5 \%$ of all estimated biomass. Cusk-eels (Ophidiidae) and small flatfish species (Pleuronectiformes) were frequently consumed (found in $29.8 \%$ and $27.7 \%$ of all stomach samples), but each taxon made up less than $1 \%$ of estimated biomass because of their small size. These results could help advance ecosystem-based management by better defining the diet of harbor porpoises in the context of potential climate changes.

Manuscript submitted 1 October 2019. Manuscript accepted 31 May 2020. Fish. Bull. 118:184-197 (2020). Online publication date: 18 June 2020. doi: 10.7755/FB.118.2.7

The views and opinions expressed or implied in this article are those of the author (or authors) and do not necessarily reflect the position of the National Marine Fisheries Service, NOAA.

\author{
Christopher D. Orphanides (contact author) ${ }^{1,3}$ \\ Frederick W. Wenzel ${ }^{2}$ \\ Jeremy S. Collie ${ }^{3}$
}

Email address for contact author: chris.orphanides@noaa.gov

${ }^{1}$ Northeast Fisheries Science Center

National Marine Fisheries Service, NOAA

28 Tarzwell Drive

Narragansett, Rhode Island 02882

\author{
${ }^{3}$ Graduate School of Oceanography \\ University of Rhode Island \\ 215 S Ferry Road \\ Narragansett, Rhode Island 02882
}

${ }^{2}$ Northeast Fisheries Science Center

National Marine Fisheries Service, NOAA

166 Water Street

Woods Hole, Massachusetts 02543

Marine mammals are affected throughout their range by fisheries bycatch (Read et al., 2006; Lewison et al., 2014; Burgess et al., 2018; Gray and Kennelly, 2018) and increasingly by climate change (Learmonth et al., 2006; Simmonds and Isaac, 2007; Sydeman et al., 2015). In order to manage and mitigate these and other threats, we need to better understand the factors behind marine mammal distributions. Regular abundance surveys and associated modeling have helped discern distributions of marine mammals in some regions (e.g., Roberts et al., 2016); however, for many species, limited quantitative information exists to explain the reasons behind their distributions. Marine mammal distribution is primarily driven by prey resources for much of the year, depending on species and reproductive life history strategies. For a small marine mammal, such as the harbor porpoise (Phocoena phocoena), with high metabolic needs and no annual breeding migration, we expect prey distribution to be a primary factor in its distribution (Read et al., 1997).

The waters of the northwest Atlantic Ocean on the continental shelf of North
America that are the primary habitat for harbor porpoises are predicted to warm at nearly 3 times the global average (Saba et al., 2016). This area has already seen documented shifts in distribution of some species (Nye et al., 2009; Kleisner et al., 2016), changes that may affect distribution and prey resources of harbor porpoises. The Gulf of Maine and Bay of Fundy stock of harbor porpoises occupies waters off the northeastern United States and its range extends from North Carolina to the Bay of Fundy and the Scotian Shelf off Nova Scotia, Canada (Waring et al., 2014). Harbor porpoises are concentrated in the Gulf of Maine and southern Bay of Fundy during the summer months and are more widely dispersed during the rest of the year, extending as far south as North Carolina from January through April (Polacheck et al., 1995; Orphanides, 2009; Waring et al., 2014). Most harbor porpoises are believed to stay in continental shelf waters throughout the year, although they have occasionally been observed along and off the shelf edge (Read and Westgate, 1997; Schofield et al., 2008; Orphanides, 2009; Waring et al., 2014). 
Bycatch of harbor porpoises was one of the most contentious issues of marine mammal management in the northeastern United States for years (Orphanides and Palka, 2013). The population of harbor porpoises on the northeastern U.S. continental shelf was considered a strategic stock under the Marine Mammal Protection Act, meaning that estimated bycatch exceeded prescribed limits. As a result, gillnet time-area closures were enacted in 2013 at a time when the groundfish fishery was already under immense stress because of reduced catch allowances and a transition to catch share management (Orphanides ${ }^{1}$; Murphy et al. ${ }^{2}$ ). Despite these management issues and the rapidly changing ocean in which harbor porpoises live, no recent research has assessed the diet of harbor porpoises as a means to better understand distribution and potential relationships to bycatch.

For the analyses described in the last 2 published papers on the diet of harbor porpoises in the northwest Atlantic Ocean, the data used were from June through September during 1989-1994 in the Gulf of Maine (Gannon et al., 1998) and from September into December during 1985-1987 in the Bay of Fundy, Canada (Recchia and Read, 1989). No published papers have ever reported assessment of the diet of harbor porpoises in southern New England or from January to May, the area and season in which much of the bycatch of harbor porpoise now occurs (Orphanides and Palka, 2013; Hatch and Orphanides ${ }^{3,4}$ ). With this study, we aimed to fill that data gap, assessing the diet of harbor porpoises on the continental shelf of North America during the winter and early spring, examining prey relative to gillnet catch, and calculating biomass consumed. We hope that our results, by improving understanding of prey consumption by harbor porpoises, can inform ecosystem-based management as fish distributions shift (Nye et al., 2009; Kleisner et al., 2016, 2017; Saba et al., 2016).

\section{Materials and methods}

\section{Stomach processing}

Stomach samples were collected by the Northeast Fisheries Observer Program (NEFOP), part of the National Marine Fisheries Service. Fisheries observers retrieved

\footnotetext{
${ }^{1}$ Orphanides, C. D. 2012. New England harbor porpoise bycatch rates during 2010-2012 associated with Consequence Closure Areas. NOAA, Natl. Mar. Fish. Serv., Northeast Fish. Sci. Cent. Ref. Doc. 12-19, 15 p. [Available from website.]

2 Murphy, T., A. Kitts, C. Demarest, and J. Walden. 2015. 2013 final report on the performance of the Northeast multispecies (groundfish) fishery (May 2013-April 2014). NOAA, Natl. Mar. Fish. Serv., Northeast Fish. Sci. Cent. Ref. Doc. 15-02, 106 p. [Available from website.]

${ }^{3}$ Hatch, J., and C. Orphanides. 2015. Estimates of cetacean and pinniped bycatch in the 2013 New England sink and mid-Atlantic gillnet fisheries. NOAA, Natl. Mar. Fish. Serv., Northeast Fish. Sci. Cent. Ref. Doc. 15-15, 26 p. [Available from website.]

${ }^{4}$ Hatch, J., and C. Orphanides. 2016. Estimates of cetacean and pinniped bycatch in the 2014 New England sink and mid-Atlantic gillnet fisheries. NOAA, Natl. Mar. Fish. Serv., Northeast Fish. Sci. Cent. Ref. Doc. 16-05, 22 p. [Available from website.]
}

animals incidentally caught in gillnet hauls on the continental shelf in southern New England during 1994-2017 (Figs. 1 and 2). These observers recorded numerous aspects of fishing trips and hauls, including locations and dates of fishing events, gear characteristics such as mesh size, and details on both the kept and discarded catch $\left(\mathrm{NEFSC}^{5}\right)$. Observers brought to port for biological sampling approximately $10 \%$ of bycaught harbor porpoises from the waters of southern New England during our study period. The majority of bycatch events occurred from January through May, with $6,7,11,16$, and 6 stomach samples collected during each of the 5 months, respectively. Size and sex of most bycaught harbor porpoises were also recorded by observers or during a necropsy (Fig. 3).

Fifty harbor porpoises from 1994 through 2017 were collected by NEFOP in our study area and considered for analysis (Fig. 1). The stomachs of 12 harbor porpoises were retrieved from comprehensive necropsies during which life history and biological information, such as reproductive status, was gathered, and 10 other necropsies were more cursory and did not include collection of maturity information on male and female reproductive organs. The remaining stomachs did not have necropsy information available because some stomachs, particularly earlier in the time series, were extracted at sea and whole animals were not brought back to shore. Therefore, animal length was used as a proxy for maturity on the basis of studies of life history, seasonality, tooth aging, and necropsies (Read and Gaskin, 1990; Read and Hohn, 1995; Wenzel, 2000).

Of the 50 stomachs collected, 4 were either empty or contained only fragments of unidentifiable otoliths and were not included in this analysis. The remaining 46 comprised 17 females, 26 males, and 3 individuals of unknown sex. Only 1 female was known to be pregnant. Harbor porpoises that were measured for size (total length) included 10 individuals that were considered young of the year $(<125 \mathrm{~cm}), 10$ juveniles $(125-139 \mathrm{~cm}), 23$ adults $(\geq 140 \mathrm{~cm})$, and 3 individuals of unknown maturity (Fig. 3) (Wenzel, 2000). Given the relatively small sample sizes in each age class, any analysis examining prey differences by maturity or size of harbor porpoises was conducted by splitting the sizes at $140 \mathrm{~cm}$, a length previously used to differentiate adults and non-adults (Wenzel, 2000).

We examined stomach contents to identify and enumerate prey and prey size through the presence of whole fish and squid (Decapodiformes) and by identification of prey by hard parts (e.g., otoliths, squid beaks, and fish jaws). These dissections generally followed the procedures outlined by Craddock et al. (2009) and Wenzel et al. (2013). We emptied the fore and main stomachs, and we separated, identified, and measured whole, relatively intact prey. We removed otoliths from intact skulls to confirm identification. Next, we examined partially digested prey to retrieve identifiable

\footnotetext{
${ }^{5}$ NEFSC (Northeast Fisheries Science Center). 2016. Northeast Fisheries Science Center Fisheries Sampling Branch observer operations manual 2016, 163 p. Fish. Sampl. Branch, Northeast Fish. Sci. Cent., Natl. Mar. Fish. Serv., NOAA, Woods Hole, MA. [Available from website.]
} 


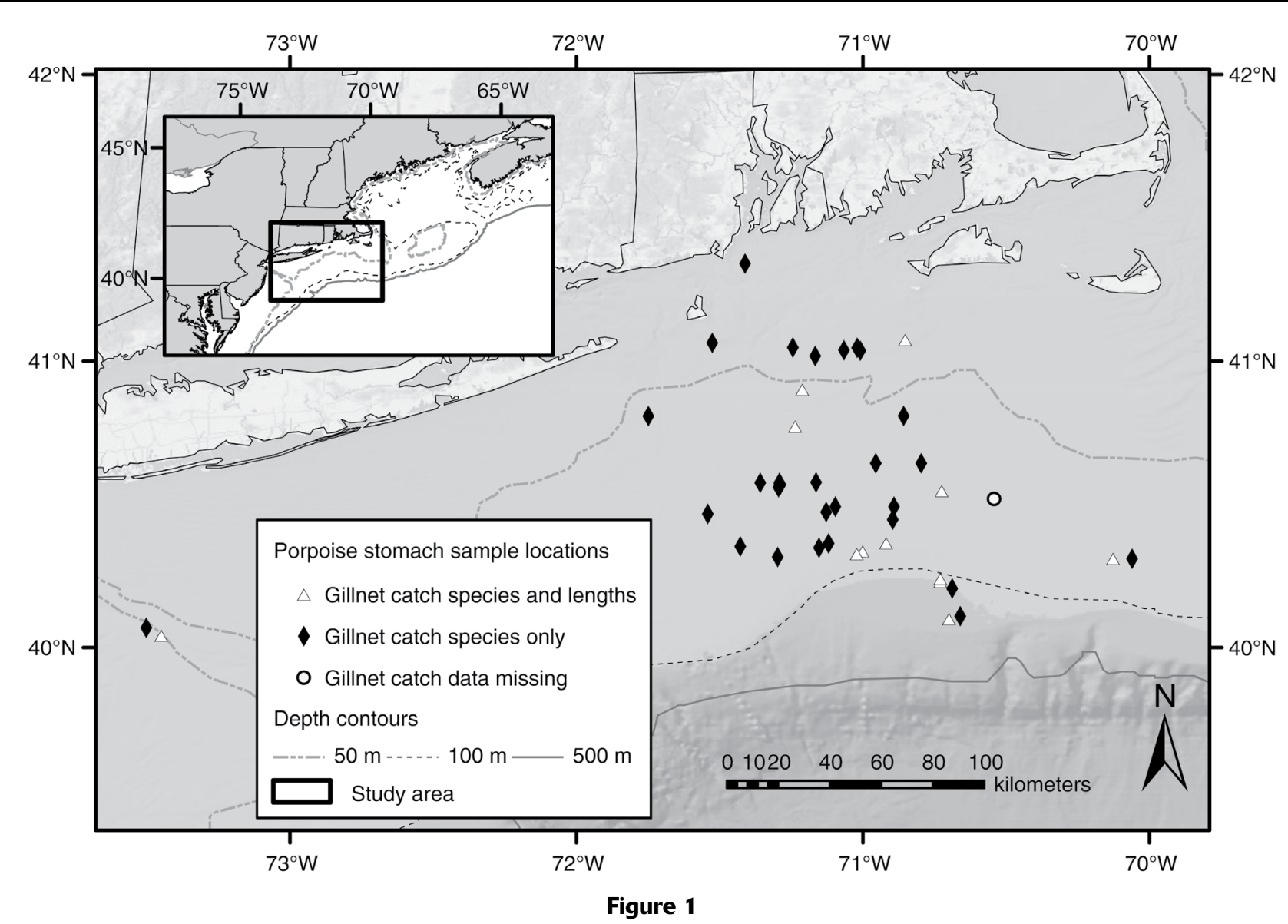

Map showing the 36 locations where harbor porpoises (Phocoena phocoena) were captured as bycatch and their stomachs $(n=46)$ were collected by the Northeast Fisheries Observer Program, National Marine Fisheries Service, on the continental shelf off southern New England between 1994 and 2017. Sampling events are categorized on the basis of the information observers were (or were not) able to collect: species identified and length measured for gillnet catch (triangles), gillnet catch species only (diamonds), or gillnet catch data missing (circles). Depth contours are provided in meters. Sources for base map: Esri, Garmin, GEBCO, NOAA NGDC, and other contributors.

hard parts (e.g., skulls, bones, otoliths, jaws, and squid beaks). We added water to well-digested prey and separated hard parts by elutriation and by decanting them through a 0.5-mm-mesh sieve. Prey were identified to the lowest taxon possible by using Northeast Fisheries Science Center (NEFSC) reference collections, professional expertise, and published guides (Brodeur ${ }^{6}$; Campana, 2004).

\section{Prey frequency and abundance}

We summarized prey items by frequency of occurrence, meaning the proportion of stomachs containing a particular prey taxon (\%FO), and by proportion of numerical abundance, meaning the percent occurrence of a specific prey type among all prey sampled $(\% \mathrm{~N})$ (Wenzel et al.,

\footnotetext{
${ }^{6}$ Brodeur, R. D. 1979. Guide to otoliths of some northwest Atlantic fishes. NOAA, Natl. Mar. Fish. Serv., Northeast Fish. Sci. Cent. Ref. Doc. 79-36, 70 p. [Available from Northeast Fish. Sci. Cent., Natl. Mar. Fish. Serv., NOAA, 166 Water St., Woods Hole, MA 02543-1026.]
}

2013). The occurrence and abundance of prey items were summarized by length and sex of the harbor porpoises and by 2 temporal groupings (1994-2006 and 2007-2017).

We used the vegan package (vers. 2.5-6; Oksanen et al., 2019) in R (vers. 3.6.1; R Core Team, 2019) to run a permutation analysis of variance (PERMANOVA) to test whether composition of prey species in stomachs of harbor porpoises varied by categories of sex, size, or study period. For this analysis, species counts were square-root transformed to minimize the influence of abundant species and species groups. The output of the PERMANOVA was checked for overdispersion. We also ran a similarity percentage analysis to examine the contribution of individual species and species groups to the overall Bray-Curtis dissimilarity.

\section{Net catch}

Fork lengths of fish and mantle lengths of squid found in stomach samples from harbor porpoises were compared against those from gillnet catch on hauls during which 

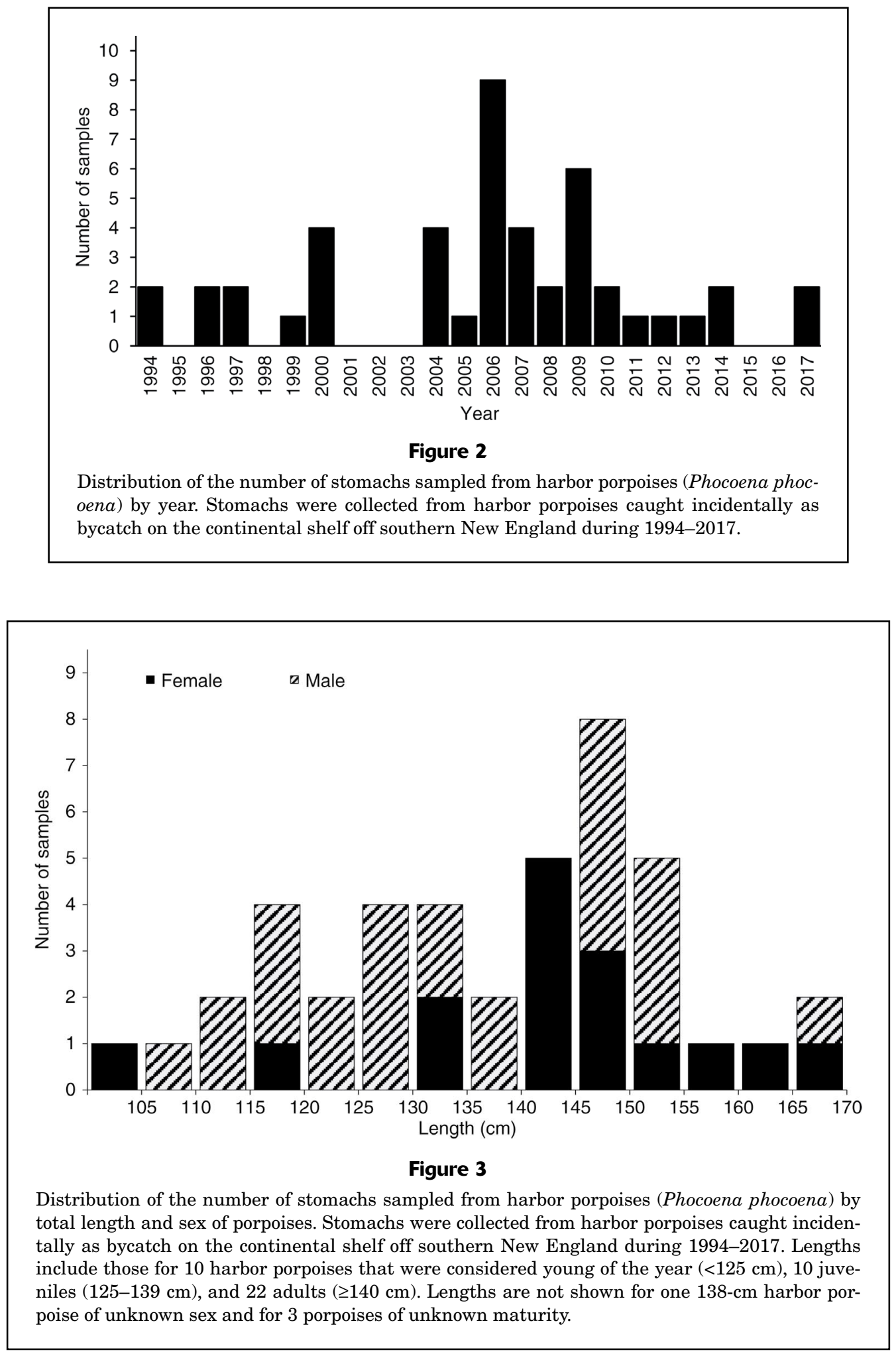

harbor porpoise stomach samples were collected. We used NEFOP data to quantify total net catch by species and length for hauls in which observers retrieved stomachs from harbor porpoises that were used in this study. Both kept and discarded net catch by species was available for
43 hauls containing 46 takes, and fish length was available for only 12 hauls completed in January, April, and May (Fig. 1). Mesh sizes of the nets for the hauls with bycatch were dominated by nets with large mesh sizes, 30.48 or $31.75 \mathrm{~cm}$ (12.0 or $12.5 \mathrm{in})$, with far fewer hauls of nets with 
medium mesh sizes, 15.24 or $16.51 \mathrm{~cm}$ ( 6.0 or $6.5 \mathrm{in})$, and no hauls of nets with small mesh sizes $(<15.24 \mathrm{~cm})$, which are rare in this region. Nets with large mesh were employed on 11 of 12 hauls with recorded fish lengths. Of the 43 hauls with documented net catch, 32 hauls were conducted with large-mesh nets and 6 hauls were done with medium-mesh nets, and mesh size of nets were unrecorded for 5 hauls.

\section{Estimation of prey lengths and weights}

Fish otoliths and squid beaks found in stomachs were measured to determine lengths and weights of prey consumed. Condition of individual otoliths was rated on a scale of 0-5 following the examples of Recchia and Read (1989) and Gannon et al. (1998). A rating of 0 was applied to otoliths extracted from skulls, a rating of 1 was given to otoliths found undamaged but loose in a stomach, and ratings of 2-5 were applied to otoliths that were slightly, moderately, significantly, or severely damaged or eroded, respectively. We used otoliths with ratings of 0-2 to estimate lengths or weights of prey; these otoliths were $28 \%$ of all otoliths. All unbroken squid beaks were measured because we observed little erosion or shrinkage of the lower rostral length used to estimate squid length. If more than 25 lower squid beaks or fish otoliths of a particular taxon were present within a stomach, and of appropriate quality for measuring, we counted all samples but only measured a randomly chosen 25 samples.

We used published equations to estimate fork lengths of fish and mantle lengths of squid from otoliths and beaks for most species (Table 1, Suppl. Table) (DuPaul and McEachran, 1973; Lange and Johnson, 1981; Recchia and Read, 1989; Clay and Clay, 1991; Hunt, 1992; Froese and Pauly $^{7}$ ). For species with suitable regressions, we assigned lengths from counted, but unmeasured, otoliths by resampling with replacement from measured otoliths within that same stomach sample and from that same taxon. This resampling assumed a similar size composition between measured and unmeasured otoliths and squid beaks. If no otoliths were measured for a specific species within a particular stomach, lengths were estimated by resampling with replacement from measured otoliths of that same taxon from all stomach samples.

We used fish and squid lengths to estimate biomass consumed per stomach by converting fish lengths to mass with length-weight formulas (Suppl. Table). Most fish lengths described above were converted to mass with a standard length-weight formula and coefficients from Wigley et al. (2003):

$$
\ln (W)=\ln (a)+b \ln (L)
$$

where $W=$ weight (in kilograms);

$$
\begin{aligned}
a & =\text { intercept; } \\
b & =\text { slope; and } \\
L & =\text { length (in centimeters). }
\end{aligned}
$$

\footnotetext{
${ }^{7}$ Froese, R., and D. Pauly (eds.). 2019. FishBase, vers. 02/2019. [World Wide Web electronic publication; available from website, accessed February 2019.]
}

\section{Table 1}

List of species, identified to the nearest taxon, found in stomachs of harbor porpoises (Phocoena phocoena) collected by the Northeast Fisheries Observer Program, National Marine Fisheries Service, when harbor porpoises were caught incidentally as bycatch on the continental shelf off southern New England during 1994-2017.

\begin{tabular}{ll}
\hline Scientific name & Common name \\
\hline Alosa aestivalis & Blueback herring \\
Alosa pseudoharengus & Alewife \\
Ceratoscopelus maderensis & Horned lanternfish \\
Citharichthys arctifrons & Gulf Stream flounder \\
Clupea harengus & Atlantic herring \\
Clupeidae & Clupeids \\
Doryteuthis (Amerigo) pealeii & Longfin inshore squid \\
Etropus microstomus & Smallmouth flounder \\
Gadidae & Gadids \\
Laemonema barbatulum & Shortbeard codling \\
Peprilus triacanthus & Butterfish \\
Melanogrammus aeglefinus & Haddock \\
Merluccius bilinearis & Silver hake \\
Ophidiidae & Cusk-eels \\
Pleuronectiformes & Flatfishes \\
Scomber scombrus & Atlantic mackerel \\
Unidentifed & Unidentified \\
Unidentified Decapodiformes & Squids \\
Urophycis spp. & True hakes \\
Urophycis chuss & Red hake \\
Urophycis regia & Spotted hake \\
Urophycis tenuis & White hake \\
\end{tabular}

If available, coefficients were applied from regional spring surveys by using both sexes of fish to best match fish found in stomach samples from harbor porpoises. No fish length-weight regression was present in Wigley et al. (2003) for Gulf Stream flounder (Citharichthys arctifrons); therefore, one was developed for this study with data from the NEFSC spring bottom-trawl survey conducted in 2017 (coefficient of multiple determination $\left[R^{2}\right]=0.94$, sample size $[n]=29$ ).

In the cases of the Gulf Stream flounder, the shortbeard codling (Laemonema barbatulum), and some taxa not identified to species, including cusk-eels (Ophidiidea), unidentified flatfish, smallmouth flounder (Etropus microstomus), unidentified or degraded samples of Gadidae, and other unidentified samples, no published equations for conversion from otolith length to fish length were found in the literature. No lengths were calculated for these taxa, aside from cusk-eels and Gulf Stream flounder. For both cusk-eels $\left(R^{2}=0.72, n=32\right)$ and Gulf Stream floun$\operatorname{der}\left(R^{2}=0.96, n=35\right)$, otolith length-fish length regressions were calculated by using samples from the NEFSC spring bottom-trawl survey conducted in 2017. A squid beakmantle length regression for longfin inshore squid (Doryteuthis (Amerigo) pealeii) was also developed by using samples from the NESFC trawl survey to ensure that 
the regression represented prey samples from the same region and season as the harbor porpoise stomach samples $\left(R^{2}=0.78, n=39\right)$ (Brodziak and Macy, 1996). This regression was also applied to squid of unknown species.

For some species, we could not obtain samples to develop regressions for conversion of otolith length to fish length (or weight), and none have been published to our knowledge. The otolith length-fish length regressions for Atlantic herring (Clupea harengus) were applied to blueback herring (Alosa aestivalis) and alewife (A. pseudoharengus) because they are in the same family. Similarly, lengths of Atlantic herring were randomly selected with replacement and were applied to 2 observations in the general clupeid category that did not have otolith length measurements. The weight regression for Atlantic herring was also applied to these 2 samples (Suppl. Table). We attempted to develop an otolith length-fish length (or weight) regression for alewife with samples from the NEFSC trawl survey but could not attain a sufficient $R^{2}$ (maximum: 0.49 ) with the 32 samples at our disposal. The lengths and weights of Gulf Stream flounder were applied in the same manner to the unidentified flatfish and smallmouth flounder because they are also in the same family. We applied the same otolith length-fish length (or weight) regression to all Urophycis species, hereafter referred to as true hakes, and to the unidentified Gadidae category.

An otolith length-fish length regression for horned lanternfish (Ceratoscopelus maderensis) yielded unreasonable size estimates (Wenzel et al., 2013). Therefore, given the small size of horned lanternfish, we estimated lengths by sampling from a normal distribution centered at a length of $5 \mathrm{~cm}$ with a standard deviation (SD) of 1 based on a size distribution between 3.8 and $6.0 \mathrm{~cm}$, with a maximum size of $8.1 \mathrm{~cm}$ for mature horned lanternfish (Froese and Pauly ${ }^{7}$ ). For horned lanternfish, we estimated weights by using a Bayesian length-weight regression $\left(\right.$ Froese and Pauly ${ }^{7}$ ).

No regressions were available for shortbeard codling and for otoliths categorized as unidentified or unidentifiable. For these groups, which constituted $2 \%$ of all otoliths, we estimated lengths and weights by randomly sampling from a truncated normal distribution defined by the mean weight and SD from all prey samples. The resulting prey length distributions were compared across study periods and categories for sex and length of harbor porpoises by using Kolmogorov-Smirnov tests.

\section{Results}

\section{Occurrence}

Frequency and numerical occurrence indicate a diet concentrated on 6 species groups: squids $(\% \mathrm{FO}=51 \%$, $\% \mathrm{~N}=19 \%$ ); red hake (U. chuss), white hake (U. tenuis), and spotted hake (U. regia) $(\% \mathrm{FO}=43 \%, \% \mathrm{~N}=22 \%)$; clupeids, comprising Atlantic herring, blueback herring, alewife, and clupeid samples of unknown species $(\% \mathrm{FO}=34 \%, \% \mathrm{~N}=8 \%)$; silver hake (Merluccius bilinearis) $(\% \mathrm{FO}=32 \%, \% \mathrm{~N}=17 \%)$; small flatfish species, including Gulf Stream flounder, smallmouth flounder, and unknown Pleuronectiformes $(\% \mathrm{FO}=28 \%, \% \mathrm{~N}=18 \%)$, and cusk-eels $(\% \mathrm{FO}=30 \%, \% \mathrm{~N}=6 \%)$ (Table 2). The combination of frequency and numerical occurrence (Costello, 1990; Amundsen et al., 1996) indicates that harbor porpoises in this region are generalist predators with true hakes and squids as the most dominant species groups (Fig. 4). However, this pooled result does not rule out potential specialization for individual harbor porpoises within the observed prey choices.

\section{Comparison with gillnet catch}

Contents of stomachs from harbor porpoises had little overlap with gillnet catch. Among 25 fish species caught in gillnets that also caught harbor porpoise used in this study, only 4 of the more rarely caught species were found in stomachs of harbor porpoises. Across 36 distinct observed hauls with porpoise bycatch, these rarely caught fish species made up $1.3 \%$ of all catch by number (both retained and discarded) and were caught in 10 hauls: haddock (Melanogrammus aeglefinus) in 2 hauls, silver hake in 1 haul, white hake in 1 haul, and Atlantic mackerel (Scomber scombrus) in 6 hauls. Only 1 species, Atlantic mackerel, was found both in the harbor porpoises caught in that net and in the net catch; Atlantic mackerel were found in 2 of 6 hauls. Dominant net-caught species $(84 \%$ of catch by number), the winter skate (Leucoraja ocellata) and the goosefish (Lophius americanus), also known as monkfish, were not found in any stomachs of harbor porpoises. In addition, there was no overlap in species lengths (Fig. 5) between recorded gillnet catch and prey in stomachs of harbor porpoise (maximum prey length: $39 \mathrm{~cm}$; minimum length of gillnet catch: $41 \mathrm{~cm}$ ). The average length of 595 measured catch items was $73.6 \mathrm{~cm}$ (SD 11.6), far larger than any prey of harbor porpoise observed in stomach contents (mean: $11.7 \mathrm{~cm}$ [SD 7.7]). These 595 catch items came from 12 hauls, all but one of which were fished with 30.48-cm-mesh nets. Total weight of fish caught in pounds was recorded for most hauls, but fish lengths were recorded on relatively few hauls.

\section{Diet composition}

We examined diet composition with multiple methods. Comparison of the diet of males and females by using PERMANOVA did not indicate significant differences in species composition of prey between harbor porpoises of different sex and size ( $<140 \mathrm{~cm}$ and $\geq 140 \mathrm{~cm})$ categories but did indicate a significant difference between study periods (1994-2006 and 2007-2017; $P$-value associated with the $F$-statistic $[P r>F]=0.025)$. Summaries of raw counts by study period and taxon contributions to the PERMANOVA indicate an apparent shift away from clupeids and toward true hakes, squids, and smaller prey (Table 3). The results of Kolmogorov-Smirnov tests indicate significant differences $(P<0.001)$ in distributions of fish fork length and squid mantle length and in estimated biomass for the above mentioned categories of size, sex, and study period 


\section{Table 2}

Summary information for fish otoliths and squid beaks found in stomachs of harbor porpoises (Phocoena phocoena) collected by the Northeast Fisheries Observer Program, National Marine Fisheries Service, when harbor porpoises were caught incidentally as bycatch on the continental shelf off southern New England between 1994 and 2017. Number of items, numerical abundance $(\% \mathrm{~N})$, number of occurrences, frequency of occurrence given as the proportion of stomachs containing a particular prey taxon $(\% \mathrm{FO})$, and number of individuals are provided for each prey item and prey group. The count of krill prey items was recorded as not applicable (NA) because these prey items were often in pieces and therefore their presence in stomachs was noted but their number could not be accurately estimated.

\begin{tabular}{|c|c|c|c|c|c|}
\hline Fish or squid taxon & $\begin{array}{c}\text { Number of } \\
\text { items }\end{array}$ & $\% \mathrm{~N}$ & $\begin{array}{l}\text { Number of } \\
\text { occurrences }\end{array}$ & $\% \mathrm{FO}$ & $\begin{array}{l}\text { Number of } \\
\text { individuals }\end{array}$ \\
\hline Squids & 582 & 19.2 & 24 & 52.2 & 348 \\
\hline Longfin inshore squid & 561 & 18.5 & 24 & 52.2 & 337 \\
\hline Unidentified squid & 21 & 0.7 & 2 & 4.3 & 11 \\
\hline Herring species & 244 & 8.1 & 16 & 34.8 & 120 \\
\hline Blueback herring & 7 & 0.2 & 2 & 4.3 & 4 \\
\hline Alewife & 151 & 5.0 & 6 & 13.0 & 78 \\
\hline Atlantic herring & 84 & 2.8 & 10 & 21.7 & 37 \\
\hline Unidentified clupeids & 2 & 0.1 & 1 & 2.2 & 1 \\
\hline Flatfish species & 544 & 18.0 & 13 & 28.3 & 279 \\
\hline Gulf Stream flounder & 486 & 16.1 & 8 & 17.4 & 245 \\
\hline Smallmouth flounder & 35 & 1.2 & 1 & 2.2 & 18 \\
\hline Unidentified flatfish & 23 & 0.8 & 5 & 10.9 & 16 \\
\hline True hakes & 675 & 22.3 & 20 & 43.5 & 360 \\
\hline Red hake & 220 & 7.3 & 9 & 19.6 & 117 \\
\hline Spotted hake & 103 & 3.4 & 6 & 13.0 & 55 \\
\hline White hake & 15 & 0.5 & 6 & 13.0 & 8 \\
\hline Unidentified (Urophycis spp.) & 337 & 11.2 & 15 & 32.6 & 180 \\
\hline Horned lanternfish & 108 & 3.6 & 1 & 2.2 & 54 \\
\hline Krill & NA & NA & 10 & 21.3 & NA \\
\hline Unidentifiable/degraded Gadidae & 17 & 0.6 & 2 & 4.3 & 9 \\
\hline Shortbeard codling & 4 & 0.1 & 1 & 2.2 & 2 \\
\hline Haddock & 70 & 2.3 & 1 & 2.2 & 35 \\
\hline Silver hake & 527 & 17.4 & 15 & 32.6 & 266 \\
\hline Cusk-eels & 172 & 5.7 & 14 & 30.4 & 94 \\
\hline Butterfish & 4 & 0.1 & 1 & 2.2 & 2 \\
\hline Atlantic mackerel & 30 & 1.0 & 6 & 13.0 & 17 \\
\hline Unidentifiable/degraded & 31 & 1.0 & 14 & 30.4 & 24 \\
\hline Unidentified & 17 & 0.6 & 6 & 13.0 & 8 \\
\hline Total & 3025 & 100.0 & & & 1618 \\
\hline
\end{tabular}

whereby fish and squid length and biomass were larger for females, large harbor porpoises $(\geq 140 \mathrm{~cm})$, and those caught during the earlier study period (weight by size: $D$ statistic $[D]=0.388$; fork length by size: $D=0.241$; weight by sex: $D=0.548$; fork length by sex: $D=0.438$; weight by year: $D=0.148$; fork length by year: $D=0.114$ ). Yet these statistical differences can be challenging to interpret because of imbalances between categories, particularly because $80 \%$ of the small harbor porpoises $(<140 \mathrm{~cm})$ were male (Table 4).

\section{Consumption estimates}

The mean estimated prey biomass derived from otoliths and squid beaks found in a harbor porpoise stomach was estimated to be $2.35 \mathrm{~kg}$ (Table 5), with an SD on a per stomach basis of $2.38 \mathrm{~kg}$ and a median value of $1.42 \mathrm{~kg}$ (Fig. 6). The distribution of total estimated live prey weight per stomach is quite variable and is skewed toward $1.0 \mathrm{~kg}$ and less, with some high weight outliers (Fig. 6). True hakes constituted the most biomass per stomach on average $(0.839 \mathrm{~kg})$, and members of Clupeidae had the secondhighest biomass $(0.518 \mathrm{~kg})$, together constituting more than half of the average estimated biomass per stomach. Squids $(0.382 \mathrm{~kg})$ and silver hake $(0.271 \mathrm{~kg})$ also contributed significantly, and together these 4 species groups (clupeids, true hakes, squids, and silver hake) constituted $85.7 \%$ of all estimated biomass. Frequently occurring but smaller prey items, such as cusk-eels and flatfish species, constituted less than $1 \%$ of estimated biomass per stomach. 


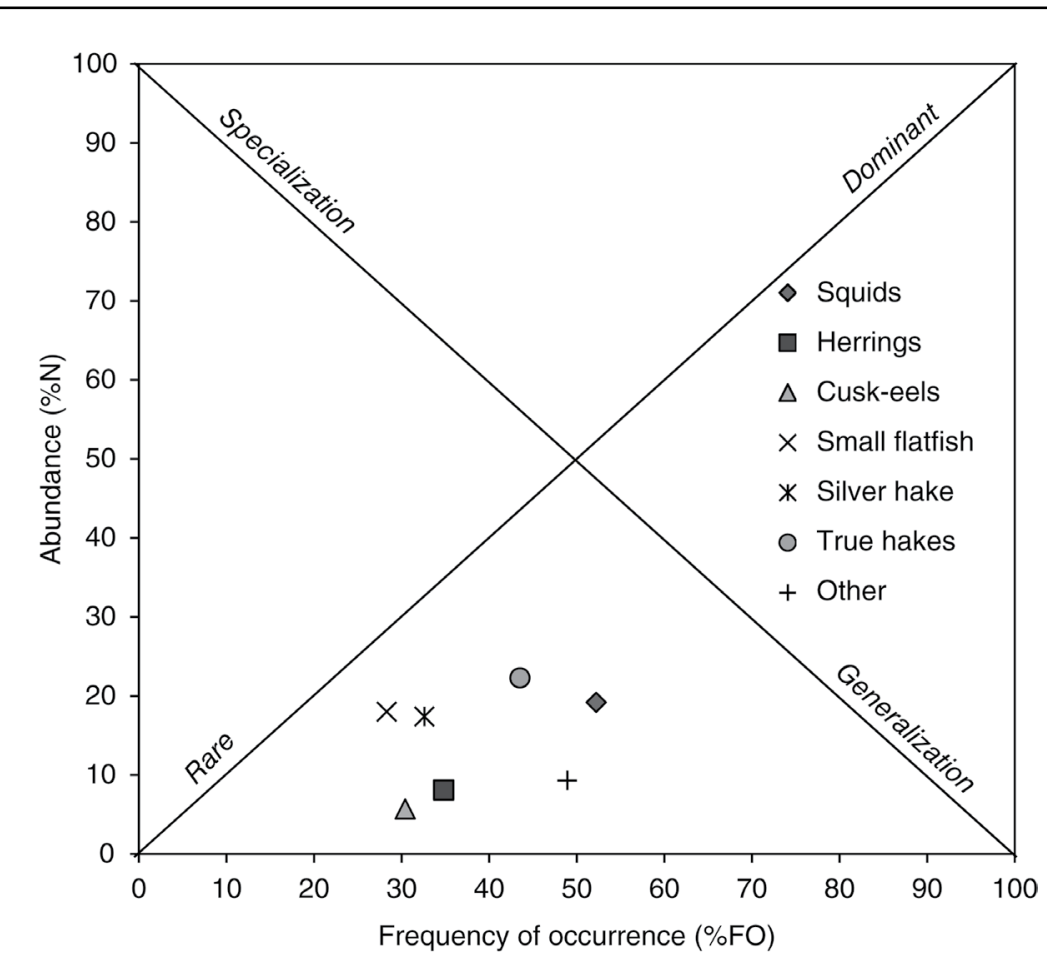

Figure 4

Costello diagram showing the relationship between abundance $(\% \mathrm{~N})$ and frequency of occurrence $(\% \mathrm{FO})$ for major species groups found in stomachs of harbor porpoises (Phocoena phocoena) collected by the Northeast Fisheries Observer Program, National Marine Fisheries Service, when harbor porpoises were caught incidentally as bycatch on the continental shelf off southern New England between 1994 and 2017. Prey importance is expressed along the axis from the bottom left (rare) to the upper right (dominant), and feeding strategy is expressed along the axis from the bottom right (generalization) to the upper left (specialization) (Costello, 1990). of Maine during the remainder of the year (Smith and Gaskin, 1974; Recchia and Read, 1989; Smith and Read, 1992; Gannon et al., 1998).

In southern New England, diet of harbor porpoises was more evenly apportioned-across 4 species groups, clupeids, true hakes, squids, and silver hake, which constituted $85.7 \%$ of the biomass - than the diet of harbor porpoise in the Gulf of Maine that was dominated by Atlantic herring, particularly in the summer (Table 5). One similarity between regions was the importance of silver hake, which was a common prey item in both this study and several previous studies (Smith and Gaskin, 1974; Recchia and Read, 1989; Smith and Read, 1992; Gannon et al., 1998).

Clupeids as prey items in southern New England were not as important in terms of biomass as in other regions and studies. Estimates of average biomass of true hakes per stomach of harbor porpoises from southern New England were larger than those of clupeids per stomach ( $840 \mathrm{~g}$ versus $518 \mathrm{~g}$ ), and true hakes as a group comprised the dominant prey taxon by number and frequency (true hakes: $\% \mathrm{~N}=22.3 \%, \% \mathrm{FO}=42.6 \%$; clupeids: $\% \mathrm{~N}=8.1 \%, \% \mathrm{FO}=34.0 \%)$. In the Gulf of Maine and Bay of Fundy, harbor porpoises were observed to depend heavily on Atlantic herring, which made up 44\% of ingested biomass in the fall (Gannon et al., 1998) and 64\% from June through September (Recchia and Read, 1989), compared with $22 \%$ of ingested biomass

\section{Discussion}

This article provides the first analysis of the diet of harbor porpoises on the continental shelf in southern New England. It is also among the first papers in 20 years to examine the diet of harbor porpoises in the northwest Atlantic Ocean and among the first to examine diet during winter and spring months (Gannon et al., 1998). This work could take on particular relevance given a regional push toward ecosystem-based fisheries management and given potential redistribution of prey due to climate change in an area that is already rapidly changing (Nye et al., 2009; Kleisner et al., 2016, 2017; Saba et al., 2016).

Harbor porpoises as a whole were found to be generalist predators in this region during the spring and winter months, primarily feeding on clupeids, true hakes, squids, silver hake, cusk-eels, and small flatfish species. Despite the relatively small sample size available for this study, prey consumption in southern New England during the winter and spring appears to differ from that reported from previous studies conducted in the neighboring Gulf in our study. One possible reason for these differences between our work and these other studies is that the caloric value of Atlantic herring is known to increase seasonally with greater feeding and spawning in the spring and summer, contributing to their seasonal importance in the Gulf of Maine (Stevenson and Scott, 2005).

Atlantic cod (Gadus morhua) were also found to be primary prey items during the summer in 2 studies (Smith and Gaskin, 1974; Recchia and Read, 1989), but no Atlantic cod were present in stomach samples in our study (Table 2). The lack of Atlantic cod in stomach samples could be in part due to a decline in abundance of Atlantic cod (Pershing et al., 2015) or a result of much of the population of Atlantic cod being typically north of our study area (Fahay et al., 1999). Alternately, it may be because most of the hauls from which harbor porpoises were taken were targeting goosefish or skate (Rajidae) with nets that had a $30.48-\mathrm{cm}$ mesh, whereas cod is typically caught with nets that have a mesh of $16.51 \mathrm{~cm}$.

In our study, squids were frequent prey $(\% \mathrm{FO}=51.1 \%)$ that constituted a significant portion of the biomass 


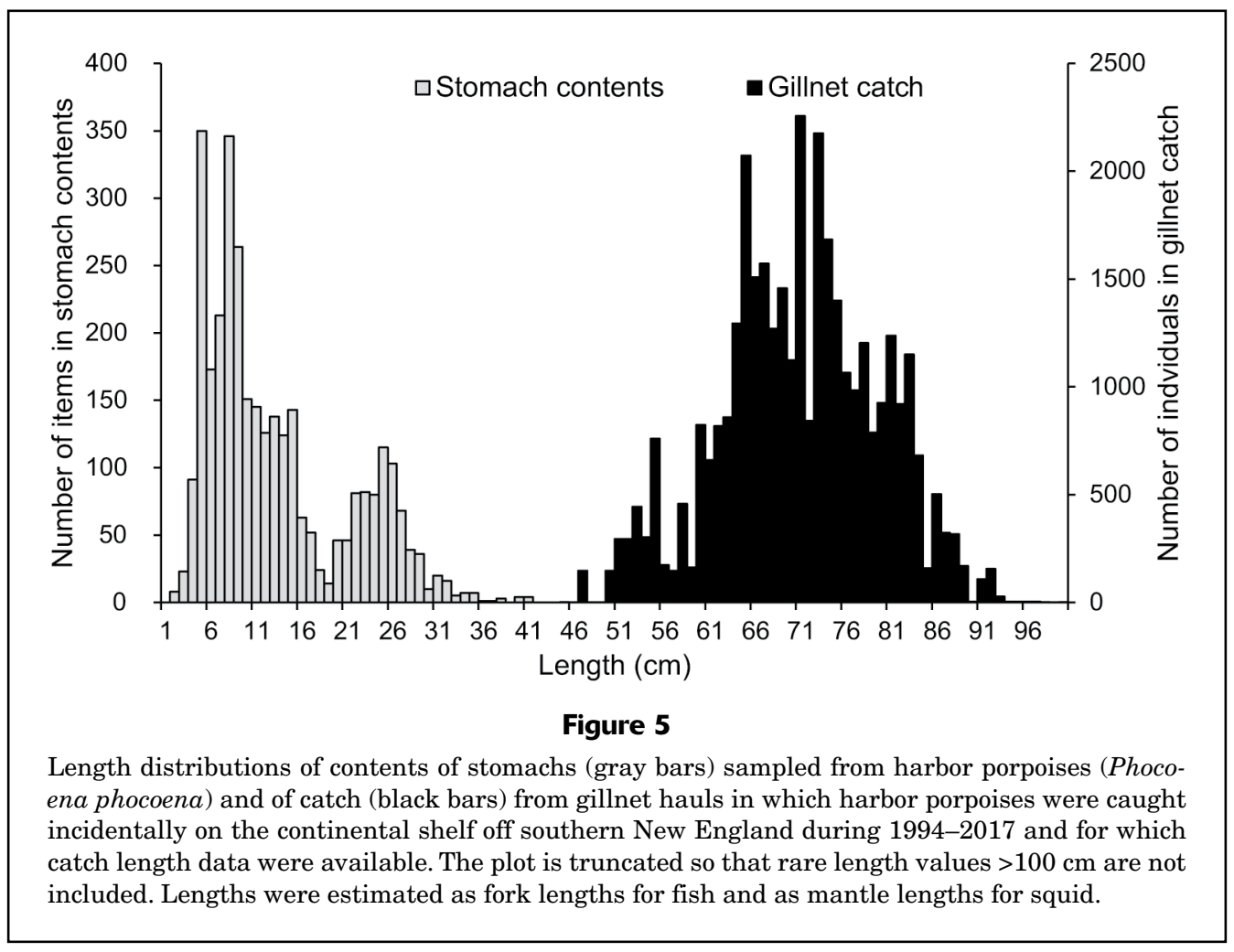

\begin{tabular}{|c|c|c|c|c|}
\hline \multicolumn{5}{|c|}{ Table 3} \\
\hline \multicolumn{5}{|c|}{$\begin{array}{l}\text { Raw counts of species groups collected from stomachs of } \\
\text { harbor porpoises (Phocoena phocoena) caught incidentally } \\
\text { on the continental shelf off southern New England, by } \\
\text { study period: } 1994-2006 \text { and } 2007-2017 \text {. Average contribu- } \\
\text { tions, with standard deviations (SDs), of species groups to } \\
\text { the permutation analysis of variance test are provided. }\end{array}$} \\
\hline \multirow[b]{2}{*}{ Species group } & \multicolumn{2}{|c|}{ Raw count } & \multicolumn{2}{|c|}{ Contribution } \\
\hline & 1994-2006 & $2007-2017$ & Average & SD \\
\hline True hakes & 56 & 619 & 0.17 & 0.17 \\
\hline Squids & 191 & 391 & 0.14 & 0.15 \\
\hline Clupeids & 207 & 37 & 0.11 & 0.16 \\
\hline Silver hake & 492 & 35 & 0.09 & 0.14 \\
\hline Flatfish species & 57 & 487 & 0.08 & 0.12 \\
\hline Cusk-eels & 20 & 152 & 0.08 & 0.10 \\
\hline Others & 29 & 252 & 0.10 & 0.10 \\
\hline
\end{tabular}

(16.2\%) of prey found in stomachs of harbor porpoises caught off southern New England from January through May but were a negligible portion of the diet during the summer and fall in the Gulf of Maine (Smith and Gaskin, 1974; Recchia and Read, 1989; Smith and Read, 1992; Gannon et al., 1998). This lack of squid in the diet of harbor porpoises could be partly due to a more limited

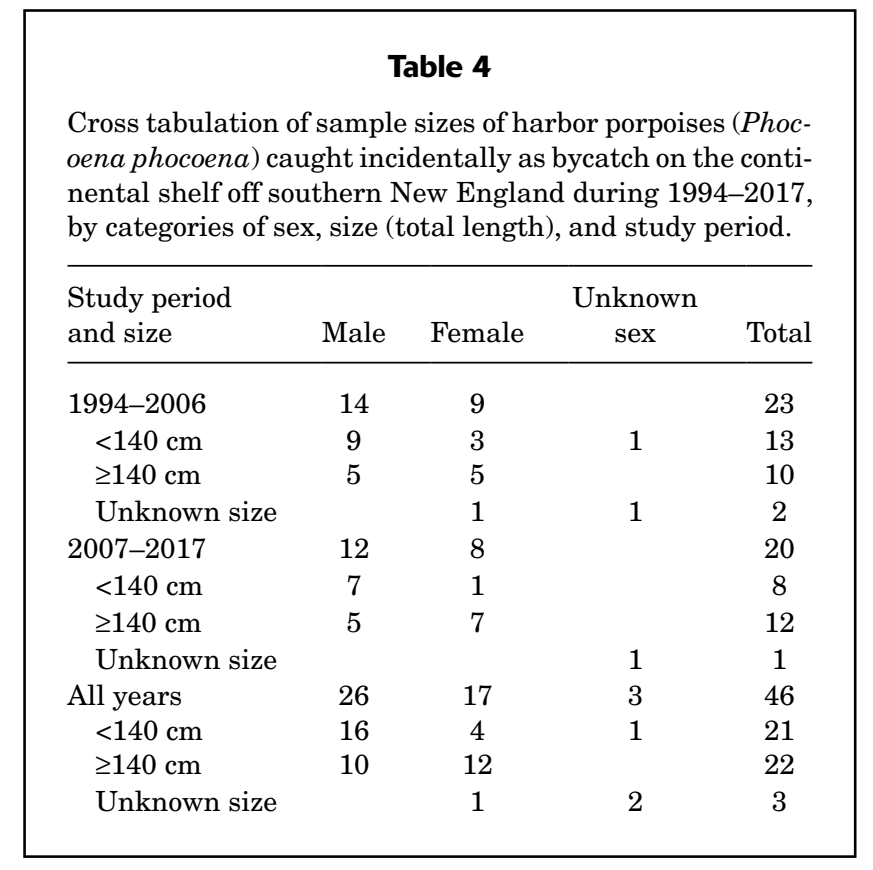

distribution of squids, particularly of longfin inshore squid, in the Gulf of Maine (Cargnelli et al., 1999a, 1999b). Small flatfish species and cusk-eels also were a significant portion of harbor porpoise diet in our work but were not seen in other studies. They were present in large numbers and 


\section{Table 5}

Measurements and estimates of biomass (total weight per stomach) for prey taxa found in stomachs of harbor porpoises (Phocoena phocoena) collected by the Northeast Fisheries Observer Program, National Marine Fisheries Service, when harbor porpoises were caught incidentally as bycatch on the continental shelf off southern New England between 1994 and 2017. Lengths were estimated as fork lengths for fish and as mantle lengths for squid. Averages and ranges of prey length and ranges of prey weight are not provided for those taxon that did not have suitable otoliths to measure due to erosion or damage or for those for which regressions for conversion of otolith length to fish length (or weight) were not available.

\begin{tabular}{|c|c|c|c|c|c|c|}
\hline \multirow[b]{2}{*}{ Fish and squid taxon } & \multicolumn{2}{|c|}{ Prey length } & \multicolumn{2}{|c|}{ Prey weight } & \multicolumn{2}{|c|}{ Stomach contents } \\
\hline & $\begin{array}{l}\text { Average } \\
(\mathrm{mm})\end{array}$ & $\begin{array}{l}\text { Range } \\
(\mathrm{mm})\end{array}$ & $\begin{array}{l}\text { Average } \\
\text { (g) }\end{array}$ & $\begin{array}{l}\text { Range } \\
\text { (g) }\end{array}$ & $\begin{array}{l}\text { Average total } \\
\text { weight }(\mathrm{g})\end{array}$ & $\begin{array}{c}\text { Average total } \\
\text { weight }(\%)\end{array}$ \\
\hline Squids & 8.0 & $5.6-16.5$ & 25.7 & $10.7-108.4$ & 381.5 & 16.2 \\
\hline Longfin inshore squid & 7.8 & $5.6-16.5$ & 24.2 & $10.7-108.4$ & 347.3 & 14.8 \\
\hline Unidentified squids & 12.8 & $5.6-16.0$ & 71.5 & $46.5-102.3$ & 34.2 & 1.5 \\
\hline Herring species & 24.8 & $11.4-34.2$ & 144.8 & $12.2-337$ & 518.3 & 22.1 \\
\hline Blueback herring & 22.7 & $27.6-30.1$ & 183.5 & $176.4-227.6$ & 31.9 & 1.4 \\
\hline Alewife & 17.8 & $11.4-34.2$ & 74.9 & $12.2-337.0$ & 253.9 & 10.8 \\
\hline Atlantic herring & 25.0 & $19.8-32.4$ & 143.8 & $64.4-286.1$ & 231.3 & 9.8 \\
\hline Unidentified clupeids & & & 26.7 & & 1.2 & 0.1 \\
\hline Flatfish species & 5.0 & $1.6-12.4$ & 0.6 & $0.0-5.5$ & 7.0 & $<0.1$ \\
\hline Gulf Stream flounder & 5.0 & $1.6-12.4$ & 0.6 & $0.0-5.5$ & 6.3 & 0.3 \\
\hline Smallmouth flounder & & & 0.4 & & 0.3 & $<0.1$ \\
\hline Unidentified flatfish & & & 0.6 & & 0.4 & $<0.1$ \\
\hline True hakes & 18.1 & $2.1-33.9$ & 53.6 & $0.04-268.8$ & 839.6 & 35.7 \\
\hline Red hake & 22.7 & $10.0-27.2$ & 74.3 & $5.3-117.4$ & 378.1 & 16.1 \\
\hline Spotted hake & 20.8 & $9.5-29.2$ & 82.2 & $0.9-17.5$ & 196.6 & 8.4 \\
\hline White hake & 28.4 & $24.9-33.4$ & 144.2 & $93.1-246.3$ & 50.2 & 2.1 \\
\hline Unidentified (Urophycis spp.) & 13.8 & $2.1-33.9$ & 27.4 & $0.04-268.8$ & 214.7 & 9.1 \\
\hline Horned lanternfish & & & 0.8 & & 1.9 & 0.1 \\
\hline Unidentifiable/degraded Gadidae & & & 76.2 & & 29.8 & 1.3 \\
\hline Shortbeard codling & & & 44.0 & & 3.8 & 0.2 \\
\hline Haddock & 14.4 & $11.5-17.0$ & 29.6 & $13.8-45.5$ & 45.1 & 1.9 \\
\hline Silver hake & 11.1 & $3.4-38.8$ & 23.4 & $0.2-382.0$ & 270.6 & 11.5 \\
\hline Cusk-eels & 10.3 & $4.8-20.3$ & 4.1 & $0.2-18.3$ & 16.6 & 0.7 \\
\hline Butterfish & 10.7 & $10.6-13.1$ & 10.2 & $8.5-15.4$ & 0.8 & $<0.1$ \\
\hline Atlantic mackerel & 25.9 & $19.3-39.9$ & 200.7 & $56.6-628.7$ & 148.3 & 6.3 \\
\hline Unidentifiable/degraded & & & 65.4 & & 68.3 & 2.9 \\
\hline Unidentified & & & 53.9 & & 18.7 & 0.8 \\
\hline Total & 11.7 & $1.6-39.9$ & 33.6 & $0.1-628.7$ & 2350.3 & 100.0 \\
\hline
\end{tabular}

frequency, although their caloric importance was limited because of their small sizes.

We found little direct overlap between prey of harbor porpoises and fish catch in the gillnets that incidentally caught harbor porpoises. The catch differed from prey in both size and composition. Fish targeted with gillnets may pursue the same prey as harbor porpoises (Bigelow and Schroeder, 1953). The limited mouth gape of harbor porpoises restricts their ability to prey on the large fish caught in gillnets, as does their feeding method of swallowing prey whole (Kastelein et al., 1997a).

Despite finding differences in distributions of prey biomass and length between size and sex of harbor porpoises and study period (females tend to be larger than males and have the added caloric burden of pregnancy;
Read et al., 1997), we found no difference in the composition of prey species by size or sex of harbor porpoises. Our findings could be influenced by the use of length to estimate maturity, but our results do match those of previous studies that indicate no difference in prey consumed between sizes of harbor porpoises except for calves (Smith and Read, 1992; Gannon et al., 1998). Harbor porpoises in our study period (January-May) and area were post-weaning (Smith and Read, 1992; Read and Hohn, 1995).

The PERMANOVA and Kolmogorov-Smirnov tests both found differences in prey between study periods (1994-2006 and 2007-2017). Between these periods, prey of harbor porpoises in our samples shifted away from calorie-rich clupeids and toward true hakes. The 


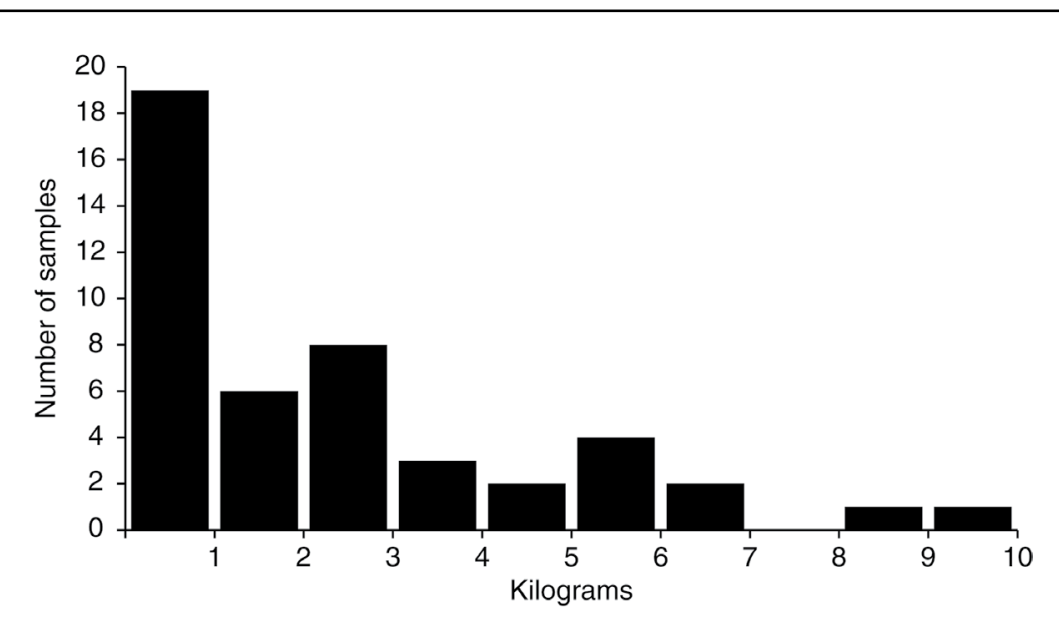

Figure 6

Histogram of estimated biomass, measured as weight in kilograms, of stomachs sampled from harbor porpoises (Phocoena phocoena) caught incidentally on the continental shelf off southern New England between 1994 and 2017.

and biomass. Otoliths and hard parts degraded during digestion could yield negatively biased length and biomass estimates, may favor species with larger and less fragile otoliths, and have an unknown retention time. These issues have been thoroughly discussed in the literature (see Bowen and Iverson, 2013). To minimize the influence of degraded otoliths, we followed the examples of Recchia and Read (1989) and Gannon et al. (1998) and used only minimally eroded otoliths for length and biomass estimation.

Accurate estimation of consumed biomass depends on digestion and food passage rates. The findings of Kastelein et al. (1997b) indicate passage of most solid remains from the stomach in $0.5-1.5 \mathrm{~h}$, although the upper limit may depend on the type of prey eaten and the size and fragility of its otoliths and squid beaks. In seals, passage rates of otoliths and squid

diet of harbor porpoises in recent years appears to have an increased reliance on squids and a decreased focus on silver hake, and the diet is generally diversified to include more smaller species (Table 3). The differences in contributions of silver hake in the diet may be skewed by 1 sample with 314 small otoliths and another sample with 123 small otoliths. The overall differences between study periods are harder to explain but could reflect shifting species distributions due to changes in climate and regional abundance (Nye et al., 2009, 2011; Richardson et al., 2014; Doubleday et al., 2016). Shifts in diet toward smaller, less calorie-dense prey could result in future shifts in distribution of harbor porpoises or in utilization of the habitat by less-mature portions of the population.

One drawback of the reliance of a diet study on hard parts is the possibility of over-counting prey because of secondary consumption. This concern may be elevated with regard to squids, true hakes, and silver hake, which are all known to be cannibalistic (Bigelow and Schroeder, 1953; Cargnelli et al., 1999a, 1999b; Steimle et al., 1999). However, direct observation during this study of numerous partially intact small fish indicates that it would be erroneous to presume that all fish or otoliths below a particular size are secondary prey. Wisniewska et al. (2016) estimated that harbor porpoises in waters of Denmark have up to 200 prey encounters per hour during the daytime, with many of those prey measuring less than $5 \mathrm{~cm}$, and as many as 550 encounters at night with a feeding success rate greater than $90 \%$. Although the results of our study do not indicate that such consistently high rates of small fish consumption were the norm, there were 2 stomachs with over 300 small otoliths recovered, one of which contained an additional 266 squid beaks.

Using hard parts for stomach content analysis also has potential consequences for estimation of prey length beaks have differed from each other and varied substantially by individual and activity level (Bigg and Fawcett, 1985; Bowen and Iverson, 2013).

We did not attempt to estimate the residence time of hard parts directly for this study, but we can back-calculate residence time by using published values of estimated daily consumption. Lockyer (2007) estimated a daily wet weight of $2.5-5.0 \mathrm{~kg}$ for Atlantic herring as prey and reported that the values varied by individual and time of year, and Smith et al. (2015) modeled daily consumption at $2.2 \mathrm{~kg}$ (80\% confidence interval: $0.94-3.30$ ). On the basis of these values, we estimated that our observed average of $2.35 \mathrm{~kg}$ for live weight per stomach equates to roughly $12-24 \mathrm{~h}$ of feeding and that the median value per stomach of $1.42 \mathrm{~kg}$ equates to roughly $7-15 \mathrm{~h}$ of feeding.

Estimates of daily consumption by species or taxa will be increasingly important as regional fisheries move toward ecosystem-based management and climate change shifts prey species distributions. For example, spring thermal habitat of red hake is predicted to move almost entirely out of southern New England within the next 20-40 years, and regional spring thermal habitat for longfin inshore squid is expected to increase by more than $200 \%$ in $60-80$ years (Kleisner et al., 2017). Despite their plastic diet, harbor porpoises could be disproportionately threatened by changes in prey distribution because of their presumed high metabolism (Read and Hohn, 1995; Wisniewska et al., 2016).

The results of our study prove that harbor porpoises do not typically prey on the same species that are caught in gillnets in the study area. Without direct overlap of gillnet catch and prey of harbor porpoises, it would be difficult to use the diet of harbor porpoises to reduce bycatch. However, with improved knowledge of prey distributions, diet data could inform estimation of potential distribution of harbor porpoises and of areas of likely gear conflict. 
Gannon et al. (1998) found that the diet of harbor porpoises during the fall in the Gulf of Maine was more diverse than during the summer in the Bay of Fundy, and they predicted that the diet of harbor porpoises would diversify as they move south out of the Gulf of Maine for the winter and spring. Their prediction appears to have been correct. On the basis of a relatively small sample size, we found a diet less reliant on Atlantic herring, with an increased importance of true hakes and squids. Silver hake also played a primary role in the diet of harbor porpoises, with cusk-eels and small flatfish species important on a numerical basis but not in terms of biomass. The shift toward true hakes, squids, and smaller species appears to have occurred more in the recent past, corresponding with abundance trends of Atlantic herring and squids. In the future, complementary techniques for examination of diet, such as DNA, stable isotope, and fatty acid analyses, could be paired with analysis of hard parts to better assess biases in this technique.

\section{Acknowledgments}

Thank you to NEFOP observers, H. Milliken, J. Kroeger, A. Crandall, M. Lyssikatos, and G. Bergstrom for data collection and processing contributions. Thanks to M. Simpkins, S. Hayes, D. Palka, D. McElroy, L. Hendrickson, L. Smith, M. Omand, and J. Hoey for support, helpful discussions, comments, and suggestions. This work was supported in part by the NOAA Advanced Study Program.

\section{Literature cited}

Amundsen, P.-A., H.-M. Gabler, and F. J. Staldvik.

1996. A new approach to graphical analysis of feeding strategy from stomach contents data-modification of the Costello (1990) method. J. Fish Biol. 48:607-614. Crossref

Bigelow, H. B., and W. C. Schroeder. 1953. Fishes of the Gulf of Maine. Fish. Bull. 53:1-577.

Bigg, M. A., and I. F. Fawcett.

1985. Two biases in diet determination of northern fur seals (Callorhinus ursinus). In Marine mammals and fisheries (J. R. Beddington, R. J. H. Beverton, and D. M. Lavigne, eds.), p. 284-291. George Allen and Unwin, London.

Bowen, W. D., and S. J. Iverson.

2013. Methods of estimating marine mammal diets: a review of validation experiments and sources of bias and uncertainty. Mar. Mamm. Sci. 29:719-754. Crossref

Brodziak, J. K. T., and W. K. Macy III.

1996. Growth of long-finned squid, Loligo pealei, in the northwest Atlantic. Fish. Bull. 94:212-236.

Burgess, M. G., G. R. McDermott, B. Owashi, L. E. Peavey Reeves, T. Clavelle, D. Ovando, B. P. Wallace, R. L. Lewison, S. D. Gaines, and C. Costello.

2018. Protecting marine mammals, turtles, and birds by rebuilding global fisheries. Science 359:1255-1258. Crossref

Campana, S. E.

2004. Photographic atlas of fish otoliths of the northwest Atlantic Ocean. Can. Spec. Publ. Fish. Aquat. Sci. 133, $284 \mathrm{p}$.
Cargnelli, L. M., S. J. Griesbach, C. McBride, C. A. Zetlin, and W. W. Morse.

1999a. Essential fish habitat source document: longfin inshore squid, Loligo pealeii, life history and habitat characteristics. NOAA Tech. Memo. NMFS-NE-146, 27 p.

Cargnelli, L. M., S. J. Griesbach, and C. A. Zetlin.

1999b. Essential fish habitat source document: northern shortfin squid, Illex illecebrosus, life history and habitat characteristics. NOAA Tech. Memo. NMFS-NE-147, 21 p.

Clay, D., and H. Clay.

1991. Determination of age and growth of white hake (Urophycis tenuis Mitchell) from the southern Gulf of St. Lawrence, Canada (including techniques for commercial sampling). Can. Tech. Rep. Fish. Aquat. Sci. 1828, 35 p.

Costello, M. J.

1990. Predator feeding strategy and prey importance: a new graphical analysis. J. Fish Biol. 36:261-263. Crossref

Craddock, J. E., P. T. Polloni, B. Hayward, and F. Wenzel.

2009. Food habits of Atlantic white-sided dolphins (Lagenorhynchus acutus) off the coast of New England. Fish. Bull. 107:384-394.

DuPaul, W. D., and J. D. McEachran.

1973. Age and growth of the butterfish, Peprilus tricanthus, in the lower York River. Chesapeake Sci. 14:205-207.

Doubleday, Z. A., T. A. Prowse, A. Arkhipkin, G. J. Pierce, J. Semmens, M. Steer, S. C. Leporati, S. Lourenço, A. Quetglas, W. Sauer, and B. M. Gillanders.

2016. Global proliferation of cephalopods. Curr. Biol. 26:R406-R407. Crossref

Fahay, M. P., P. L. Berrien, D. L. Johnson, and W. W. Morse.

1999. Essential fish habitat source document: Atlantic cod, Gadus morhua, life history and habitat characteristics. NOAA Tech. Memo. NMFS-NE-124, 34 p.

Gannon, D. P., J. E. Craddock, and A. J. Read.

1998. Autumn food habits of harbor porpoises, Phocoena phocoena, in the Gulf of Maine. Fish. Bull. 96:428-437.

Gray, C. A., and S. J. Kennelly.

2018. Bycatches of endangered, threatened and protected species in marine fisheries. Rev. Fish Biol. Fish. 28:521541. Crossref

Hunt, J. J.

1992. Morphological characteristics of otoliths for selected fish in the northwest Atlantic. J. Northwest Atl. Fish. Sci. 13:63-75.

Kastelein, R. A., C. Staal, A. Terlouw, and M. Muller.

1997a. Pressure changes in the mouth of a feeding harbor porpoise (Phocoena phocoena). In The biology of the harbor porpoise (A. J. Read, P. R. Wiepkema, and P. E. Nachtigall, eds.), p. 279-291. De Spil Publishers, Woerden, Netherlands.

Kastelein, R. A., S. H. Nieuwstraten, and M. W. A. Verstegen.

1997b. Passage time of carmine red dye through the digestive tract of harbour porpoises (Phocoena phocoena). In The biology of the harbour porpoise (A. J. Read, P. R. Wiepkema, and P. E. Nachtigall, eds.), p. 265-275. De Spil Publishers, Woerden, Netherlands.

Kleisner, K. M., M. J. Fogarty, S. McGee., A. Barnett, P. Fratantoni,

J. Greene, J. A. Hare, S. M. Lucey, C. McGuire, J. Odell, et al. 2016. The effects of sub-regional climate velocity on the distribution and spatial extent of marine species assemblages. PLoS ONE 11(2):e0149220. Crossref

Kleisner, K. M., M. J. Fogarty, S. McGee, J. A. Hare, S. Moret, C. T. Perretti, and V. S. Saba.

2017. Marine species distribution shifts on the U.S. Northeast Continental Shelf under continued ocean warming. Prog. Oceanogr. 153:24-36. Crossref 
Lange, A. M. T., and K. L. Johnson.

1981. Dorsal mantle length-total weight relationships of squids Loligo pealei and lllex illecebrosus from the Atlantic coast of the United States. NOAA Tech. Rep. NMFS SSRF-745, 18p.

Learmonth, J. A., C. D. MacLeod, M. B. Santos Vazquez, G. J. Pierce, H. Q. P. Crick, and R. A. Robinson.

2006. Potential effects of climate change on marine mammals. Oceanogr. Mar. Biol. Annu. Rev. 44:431-464.

Lewison, R. L., L. B. Crowder, B. P. Wallace, J. E. Moore, T. Cox, R. Zydelis, S. McDonald, A. DiMatteo, D. C. Dunn, C. Y. Kot, et al.

2014. Global patterns of marine mammal, seabird, and sea turtle bycatch reveal taxa-specific and cumulative megafauna hotspots. Proc. Natl. Acad. Sci. USA 111:52715276. Crossref

Lockyer, C.

2007. All creatures great and smaller: a study in cetacean life history energetics. J. Mar. Biol. Assoc. U.K. 87:1035-1045. Crossref

Nye, J. A., J. S. Link, J. A. Hare, and W. J. Overholtz.

2009. Changing spatial distribution of fish stocks in relation to climate and population size on the Northeast United States continental shelf. Mar. Ecol. Prog. Ser. 393:111-129. Crossref

Nye, J. A., T. M. Joyce, Y.-O. Kwon, and J. S. Link.

2011. Silver hake tracks changes in Northwest Atlantic circulation. Nat. Commun. 2:412. Crossref

Oksanen, J., F. G. Blanchet, M. Friendly, R. Kindt, P. Legendre,

D. McGlinn, P. R. Minchin, R. B. O’Hara, G. L. Simpson,

P. Solymos, et al.

2019. vegan: community ecology package. $R$ package, vers. 2.5-6. [Available from website, accessed July 2019.]

Orphanides, C. D.

2009. Protected species bycatch estimating approaches: estimating harbor porpoise bycatch in U.S. northwestern Atlantic gillnet fisheries. J. Northwest Atl. Fish. Sci. 42:55-76. Crossref

Orphanides, C. D., and D. L. Palka.

2013. Analysis of harbor porpoise gillnet bycatch, compliance, and enforcement trends in the US northwestern Atlantic, January 1999 to May 2010. Endang. Species Res. 20:251-269. Crossref

Pershing, A. J., M. A. Alexander, C. M. Hernandez, L. A. Kerr,

A. Le Bris, K. E. Mills, J. A. Nye, N. R. Record, H. A. Scannell,

J. D. Scott, et al.

2015. Slow adaptation in the face of rapid warming leads to collapse of the Gulf of Maine cod fishery. Science 350:809 812. Crossref

Polacheck, T., F.W. Wenzel, and G. Early.

1995. What do stranding data say about harbor porpoises (Phocoena phocoena)? Rep. Int. Whaling Comm. Spec. Issue 16:169-179.

$\mathrm{R}$ Core Team.

2019. R: a language and environment for statistical computing. R Foundation for Statistical Computing, Vienna, Austria. [Available from website, accessed July 2019 .

Read, A. J., and D. E. Gaskin.

1990. Changes in growth and reproduction of harbor porpoises, Phocoena phocoena, from the Bay of Fundy. Can. J. Fish. Aquat. Sci. 47:2158-2163. Crossref

Read, A. J., and A. A. Hohn.

1995. Life in the fast lane: the life history of harbor porpoises from the Gulf of Maine. Mar. Mamm. Sci. 11:423-440. Crossref
Read, A. J., and A. J. Westgate.

1997. Monitoring the movements of harbour porpoises (Phocoena phocoena) with satellite telemetry. Mar Biol. 130:315322. Crossref

Read, A. J., P. R. Wiepkema, and P. E. Nachtigall.

1997. The biology of the harbour porpoise, 410 p. De Spil Publishers, Woerden, Netherlands.

Read, A. J., P. Drinker, and S. Northridge.

2006. Bycatch of marine mammals in U.S. and global fisheries. Conserv. Biol. 20:163-169. Crossref

Recchia, C. A., and A. J. Read.

1989. Stomach contents of harbour porpoises, Phocoena phocoena (L.), from the Bay of Fundy. Can. J. Zool. 67:2140 2146. Crossref

Richardson, D. E., M. C. Palmer, and B. E. Smith.

2014. The influence of forage fish abundance on the aggregation of Gulf of Maine Atlantic cod (Gadus morhua) and their catchability in the fishery. Can. J. Fish. Aquat. Sci. 71:1349-1362. Crossref

Roberts, J. J., B. D. Best, L. Mannocci, E. Fujioka, P. N. Halpin,

D. L. Palka, L. P. Garrison, K. D. Mullin, T. V. N. Cole,

C. B. Khan, et al.

2016. Habitat-based cetacean density models for the U.S. Atlantic and Gulf of Mexico. Sci. Rep. 6:22615. Crossref

Saba, V. S., S. M. Griffies, W. G. Anderson, M. Winton, M. A. Alexander, T. L. Delworth, J. A. Hare, M. J. Harrison,

A. Rosati, G. A. Vecchi, et al.

2016. Enhanced warming of the northwest Atlantic Ocean under climate change. J. Geophys. Res., Oceans. 121:118132. Crossref

Schofield, T. D., G. Early, F. W. Wenzel, K. Matassa, C. Perry,

G. Beekman, B. Whitaker, E. Gebhard, W. Walton, and M. Swingle. 2008. Rehabilitation and homing behavior of a satellitetracked harbor porpoise (Phocoena phocoena). Aquat. Mamm. 34:1-8. Crossref

Simmonds, M. P., and S. J. Isaac.

2007. The impacts of climate change on marine mammals: early signs of significant problems. Oryx 41:19-26. Crossref

Smith, G. J. D., and D. E. Gaskin.

1974. The diet of harbor porpoises (Phocoena phocoena (L.)) in coastal waters of eastern Canada, with special reference to the Bay of Fundy. Can. J. Zool. 52:777-782. Crossref

Smith, L. A., J. S. Link, S. X. Cadrin, and D. L. Palka.

2015. Consumption by marine mammals on the Northeast U.S. continental shelf. Ecol. Appl. 25:373-389. Crossref

Smith, R. J., and A. J. Read.

1992. Consumption of euphausiids by harbour porpoise (Phocoena phocoena) calves in the Bay of Fundy. Can. J. Zool. 70:1629-1632. Crossref

Steimle, F. W., W. W. Morse, P. L. Berrien, and D. L. Johnson.

1999. Essential fish habitat source document: red hake, Urophycis chuss, life history and habitat characteristics. NOAA Tech. Memo. NMFS-NE-133, $34 \mathrm{p}$

Stevenson, D. K., and M. L. Scott.

2005. Essential fish habitat source document: Atlantic herring, Clupea harengus, life history and habitat characteristics, 2nd ed. NOAA Tech. Memo. NMFS-NE-192, 84 p.

Sydeman, W. J., E. Poloczanska, T. E. Reed, and S. A. Thompson.

2015. Climate change and marine vertebrates. Science 350:772-777. Crossref

Waring, G. T., E. Josephson, K. Maze-Foley, and P. E. Rosel (eds.).

2014. U.S. Atlantic and Gulf of Mexico marine mammal stock assessments-2013. NOAA Tech. Memo. NMFSNE-228, 449 p. 
Wenzel, F. W.

2000. An examination of the distribution and causes of harbor porpoise (Phocoena phocoena) strandings in Massachusetts waters. M.S. thesis, 129 p. Northeastern Univ., Boston, MA.

Wenzel, F. W., P. T. Polloni, J. E. Craddock., D. P. Gannon, J. R. Nicolas, A. J. Read, and P. E. Rosel.

2013. Food habits of Sowerby's beaked whales (Mesoplodon bidens) taken in the pelagic drift gillnet fishery of the western North Atlantic. Fish. Bull. 111:381-389. Crossref
Wigley, S. E., H. M. McBride, and N. J. McHugh.

2003. Length-weight relationships for 74 fish species collected during NEFSC research vessel bottom trawl surveys, 1992-99. NOAA Tech. Memo. NMFS-NE-171, 26 p.

Wisniewska, D. M., M. Johnson, J. Teilmann, L. Rojano-

Doñate, J. Shearer, S. Sveegaard, L. A. Miller, U. Siebert, and P. T. Madsen.

2016. Ultra-high foraging rates of harbor porpoises make them vulnerable to anthropogenic disturbance. Curr. Biol. 26:1441-1446. Crossref 